\title{
A COMPARATIVE ANALYSIS OF THE DESIGN OF SPECIAL ECONOMIC ZONES: THE CASE OF SOUTH AFRICA, MALAYSIA AND INDONESIA
}

\author{
Nadea le Roux* \\ University of Pretoria
}

Received: March 2016

\author{
Anculien Schoeman\# \\ University of Pretoria
}

Accepted: August 2016

\begin{abstract}
The South African government is dedicated to improving the country's economy. The establishment of economic zones is used throughout the world as a method to improve a country's economic growth. The main purpose of this study is to compare the key aspects of the new Special Economic Zones (SEZ) Programme in South Africa to those of Malaysia and Indonesia, since both these countries have successfully established SEZs which have contributed to the development of these countries. It was found that South Africa's programme design was on par with that of these two countries, but further recommendations were made.
\end{abstract}

Keywords

Special economic zones, SEZ Programme, South Africa, Malaysia, Indonesia, unemployment, foreign direct investment, exports.

*Ms N le Roux was a master's student in the Department of Taxation, University of Pretoria, South Africa.

\#Ms A Schoeman is a senior lecturer in the Department of Taxation, University of Pretoria, South Africa [anculien.schoeman@up.ac.za]. 


\section{INTRODUCTION}

"Change is inevitable. Progress is optional" (Robbins 2014). In his budget speech in 2008, Finance Minister Trevor Manuel indicated that the South African government is dedicated to improving the country's economy by striving to increase local and foreign investment levels and increase exports in order to reduce poverty and unemployment (National Treasury, 2008:iii). One of the major problems in improving the economy is the unemployment rate in South Africa which, in 2013, was $24 \%$, while the unemployment rate amongst the youth was 50\% (Sala-i-Martín \& Schwab, 2013:43). It is critical that South Africa improves its educational standards to ensure that the labour market becomes more effective. In addition, South Africa's export performance is restricted by the weak global demand for its manufactured products. In 2013, South Africa had one of the largest current account shortfalls globally (Department of Research and Information, 2013:7). One way to combat unemployment and increase foreign investment and exports is the introduction of special economic zones (SEZs).

The objective of the comparison through available literature is to determine whether the new S\&Z Programme in South Africa is internationally competitive and on par with similar programmes in Malaysia and Indonesia. These key aspects will also be compared with the Foreign Investment Advisory Service (FIAS) best practices to determine whether they have been incorporated into the legislation. The key aspects of the SEZ programme as identified from the Department of Trade and Industry (DTI) study (DTI:2012) and the SEZ Act include the governance and ownership structure of the SEZs; the incentives offered to investors; the establishment of One-Stop-Shops; the types of SEZs to be established, as well as how the SEZs should be marketed and funded. A One-StopShop is defined as a single location which provides all the services that are required for a specific activity and is considered to be one of the best strategies to promote foreign direct investment (Africa Institute of South Africa \& DTI, 2013:1-2).

Malaysia and Indonesia were chosen for this study as both countries have successfully established SEZs which have contributed to the economic development of these countries. Indonesia was also chosen as both Indonesia and South Africa are part of the Group of Twenty (G20) major developing economies and are rich in natural resources $(G 20,2014)$. A total of 28 companies were located in the Bayan Lepas (Malaysia) free industrial zone (FIZ) by the end of 1973, creating 21200 jobs (United Nations Development Programme (UNDP), 2006:33). By 2008, 89000 new jobs had been created as a result of the implementation of the SEZ Programme (Chai \& Im, 2009:9).

SEZs are "spatially delimited areas within an economy that function with administrative, regulatory, and often fiscal regimes that are different (typically more liberal) from those of the domestic economy" (Farole, 2011:17). In 2008, FIAS conducted a study looking at 30 years of experience in economic zones, considering the successes thereof and what the effects of these policies were on the economy of countries worldwide. From this study, a framework of best practice for zone development was designed in order to assist countries in optimising future results (FIAS, 2008:1). As Farole observed (2011:18), although there have been 30 years of studies in the field of special economic zones, there has not been any "systematic, data-driven analysis on the performance of economic zones."

The S\&Z Act (16/2014) (hereafter referred to as the S\&Z Act) was published in South Africa on 19 May 2014. The "zones" have, however, not yet been made known by the Minister of Finance. Going back in history, in 1968, South Africa introduced the Babelegi programme about 40 kilometres north of Pretoria. This refers to the de-centralisation of some economic activities, particularly the manufacturing sector, away from the country's metropolitan hubs to the "Bantu 
Homelands" in order to provide black people with employment opportunities in new work centres (Rogerson, 1974:126). However, the success thereof is doubtful as many factories in Babelegi are standing empty and unemployment is high in this area (Tiro, 2014: 6). The South African government established the Industrial Development Zone (IDZ) Programme in 2000 in an effort to reposition itself in the world economy after the economic challenges faced by South Africa after 1994, when the first democratic election took place. However, weaknesses in the IDZ Programme resulted in the government introducing the new SEZ Programme in 2014 (DTI, 2012:9) in an attempt to address the country's economic issues. One of the main limitations of the IDZ Programme is the requirement that IDZs had to be linked to a seaport or international airport. This requirement led to the exclusion of various regions in the country which had industrial potential but could not benefit from these programmes as they did not meet the IDZ criteria.

The DTI (2012) determined why the IDZ Programme was unsuccessful, while the Africa Institute of South Africa together with the DTI (2013) did a study on the proposed One-Stop-Shop model for South Africa, in which a brief comparison was made between the then proposed SEZ Programme in South Africa and SEZs in other countries. Farole (n.d.) conducted a case study in six African countries and four other regions, based on secondary research and did interviews with investors, zone developers and operators as well as other stakeholders. Surveys of investors operating in the zones were also conducted. It was found, among other things, that the zones have resulted in more jobs for the poor, but that the quality of employment was still failing. It was also found that zones that are in areas with more labour, consumers and suppliers tend to be more successful. Bräutigam and Xiaoyang (2011) analysed the background, motives and implementation of zones by the Chinese in Africa. They found that although the cooperation could result in sustainable industrialisation, they identified "serious political, economic and social challenges". Aggarwal (2007) performed a study to determine the human development effects of SEZs in India. It was found that although wages and incentives benefits were good in the zones, the SEZs had limited success in attracting investment and promoting exports. As far as could be determined, no research has been done to compare the key aspects of South Africa's SEZ Programme with SEZ Programmes in Malaysia and Indonesia, which have faced similar economic challenges but where these programmes have been successful in developing those countries. The IDZ Programme is considered to have had limited success in achieving its primary aim of attracting investment to South Africa. Therefore, it is important to assess whether the new SEZ Programme will be able to fulfil its intended mandate to foster job creation, economic growth and attract much needed local and foreign investment (DTI, 2012:8). A comparative approach to SEZ programmes in other developing countries will add to the body of literature available that shows the similarities and differences between the various programmes. Suggestions will also be made on how the programme design could be improved.

The comparative analysis is guided by two questions:

- To what extent are the key aspects of the SEZ Programme design in South Africa similar to the SEZ Programmes in Malaysia and Indonesia?

- What could be amended or added to the current SEZ Act to improve its design?

This study will now continue with a literature review, providing a description of SEZs throughout the world. After that, a brief background regarding the SEZs in South Africa, Malaysia and Indonesia will be given. The method followed will then be discussed, followed by the comparison of the new SEZ Programme in South Africa with those of Malaysia and Indonesia. The study will then conclude and provide recommendations for future studies. 


\section{BACKGROUND ON SEZS}

\subsection{Introduction}

SEZs have developed throughout the world, both in terms of form and scope, since the first SEZ, the Shannon Free Zone, was established in Ireland in 1959 (Engman, Onnodera \& Pinali, 2007:11). The term S\&Z is the term used to describe the different types of economic zones that exist in the world (Farole, 2011:26).

The components of the term "SEZ" can be broken down as follows:

- Special: Refers to the regulatory regime that differentiates the specific zone from the rest of the country's economy.

- Economic: Refers to the type of activities allowed within the specific zones.

- Zone: Refers to the physical or legally restricted economic space contained within the specific area (Farole, 2011:26-27).

SEZs are defined as geographically enclosed areas which are administered by a single dedicated regulatory body in a specific country and have a different regulatory system from the rest of the economy of a country. SEZs usually offer a high-quality infrastructure which supports the activities of the companies and authorities operating within the SEZs. Usually, the infrastructure within an SEZ consists of manufacturing or industrial parks, as well as infrastructure used for transport which connects the SEZ to its different sources and markets (Farole, 2011:23-25). Furthermore, an SEZ is an economic development tool which offers certain tax and other incentives to attract local and foreign investments to the specific zone in an attempt to boost economic growth (DTI, 2012:13).

Best practice as determined by the FIAS indicates that the SEZ policies include incentives such as tax incentives, import and export duty exemptions, efficient administration, a separate customs controlled area with efficient controls and processes, as well as generous foreign trade policies. The goal of setting up an SEZ is to increase the competitive environment of a country through an increase in investment and a decrease in business costs (FIAS, 2008:12).

Good practice guidelines for designing an SEZ model for a country incorporate the promotion of the private instead of the public development of economic zones. These businesses registered under an SEZ programme should operate in the same area as businesses not registered under this programme. The development of an organised, legal, regulatory and institutional framework will ensure that there is sufficient facilitation and regulation of the SEZs. The SEZ regime should be flexible enough to allow for a variety of activities, manufacturing or commercial, to take place within the SEZ (FIAS, 2008:5).

\subsection{The growth of special economic zones}

Economic zones are used worldwide and have grown in popularity. According to a study done by the International Labour Organisation in 2003 (in FIAS, 2008:7), there were only 79 economic zones in 25 countries all over the world in 1975 . These economic zones employed roughly 800,000 people. In 2008, the FIAS (2008:23) indicated that at that stage there were about 2301 economic zones operating in 119 developing countries and that the economic zones accounted for approximately $\$ 200$ billion in exports per year and employed around 40 million people directly within the developing countries. Well-designed economic zones have proved to be a tool for economic growth 
and job creation around the world (Centre for Development and Enterprise, 2012:8). This reemphasises the importance of a well-designed SEZ Programme in South Africa.

\subsection{Special economic zones in South Africa}

"South Africa is confronted with serious socio-economic challenges including subdued economic growth, high levels of unemployment, income inequality and abject poverty as well as spatial development challenges and regional disparities" (DTI, 2012:9). During the late 1940s, the apartheid system was implemented, with the white minority government oppressing the civil rights of other races in South Africa. Later, sanctions were actioned against South Africa whereby foreign countries no longer invested in South Africa in an attempt to show their disapproval of South Africa's political regime and bringing about political change in South Africa (Laverty, 2007). These sanctions were only lifted in 1994 when the first democratically elected government was voted into parliament.

Despite the progress made on the three operational IDZs implemented in 2000, the IDZ Programme designed to reposition South Africa in the world economy after the years of apartheid and sanctions did not meet the expectations of the South African government. The DTI believes that more could have been accomplished through this programme. Subsequently, the DTI commenced with a review process of the IDZ Programme in an attempt to address the challenges faced by the IDZs (Minister of Trade and Industry, 2013:18). IDZs have not achieved the results expected from the stakeholders owing to weak governance and stakeholder arrangements, lack of incentives offered, flaws in the design of the programme, support measures that were not in place, lack of real funding arrangements (DTI, 2012:11-21), and an ineffective marketing strategy (DTI, 2013:12). In addition to the failure of the IDZ Programme, developments in the global economic environment, such as the formation of BRICS (Brazil, Russia, India, China and South Africa), resulted in a proposed SEZ Programme (DTI, 2012:15) after the review of the IDZ Programme.

In terms of section 39 of the new SEZ Act, the current IDZ Programme will be expanded into the new SEZ Programme. All current IDZs and all new IDZs will be regarded as SEZs and will have to comply with the SEZ legislation. This will allow for the implementation of the different types of economic zones into the new SEZ Programme in accordance with the change of national economic development priorities and regional development requirements. The new SEZ Programme has been designed to address the issues which resulted in the IDZ Programme not meeting its objectives by creating a governmental framework that will control the operation and designation of the new SEZs (DTI, 2013:2).

The DTI identified SEZs as instruments which have the potential to steer South Africa's economy in the direction of economic growth. The implementation is based not only on the success of SEZs in other parts of the world, but also on the potential for successful SEZs in South Africa. South Africa is rich in natural and mineral resources and has sufficient availability of land. It has an effective regulatory environment and acts as a gateway to Africa. It has a high score in facilitating the practice of business. These elements provide a good foundation on which the South African economic zones can assist in building economic growth (DTI, 2012:17).

The main objectives for establishing SEZs in South Africa according to the DTI (2012:18) are to promote the value and usefulness of South Africa's natural and mineral resources. It also wants to attract local and foreign investments and develop infrastructure to support different industries. It wants to accelerate the growth in exports and create employment. 
SEZs have the potential to develop South Africa's industrial base, focusing on the areas which require growth. By specifically addressing the issues that affect the cost of doing business in South Africa, SEZs create an attractive environment for investors (Deloitte, 2013:1).

\subsection{Special economic zones in Malaysia}

Asia has been at the forefront of SEZ development over the past three decades (FIAS, 2008:27). The first country in Asia to implement SEZs was Malaysia (Wahyuni, Anoviar \& Santoso, 2012:6). Malaysia, previously Malaya, faced political challenges in that it had been colonised for over 400 years by four different powers before it finally gained independence in 1957 (Thomas, 2011). Penang is one of the states in Malaysia in which SEZs have been established. These S\&Zs focus mainly on the electronics industry and Penang is one of the most successful states in Malaysia today. The country was faced with the challenge of increased unemployment during the late 1960s when the unemployment rate was about $14.5 \%$ in Penang. With Malaysia facing these high unemployment levels, together with the loss of the free port status in Penang, the Penang state government decided to transform its economy (Chai \& Im, 2009:3).

The establishment of Malaysia's first SEZ, the Bayan Lepas FIZ in Penang, took place in August 1971 and is considered to be a move towards greater industrialisation and the beginning of the electronics industry in Malaysia (Chai \& Im, 2009:8). The provision of good infrastructure in the Bayan Lepas FIZ, which allowed for duty-free import and export of goods into the zone with minimal involvement of customs, drew foreign manufacturers involved in exports to move or expand their operations to the Bayan Lepas FIZ (Chai \& Im, 2009:8).

A total of 28 companies were located in the Bayan Lepas FIZ by the end of 1973, creating 21200 jobs (UNDP, 2006:33). By the end of 2008, when the four phases of the FIZ had been concluded, total foreign investment of Malaysian Ringgit (RM) 14.6 billion had been received, resulting in the creation of over 89000 new jobs (Chai \& Im, 2009:9). Penang has been transformed to become the manufacturing hub for state-of-the-art companies such as Motorola, Intel, IBM and Dell (Wahyuni et al., 2012:2). It is remarkable that Penang's unemployment rate as at 2008 was only $2.4 \%$ (Chiang, 2011:11).

Malaysia has been very successful in the establishment of $S E Z s$ as can be seen from the growth of the first SEZ, the Bayan Lepas SEZ in Penang and the fact that Penang has become one of the most successful states in Malaysia (Wahyuni et al., 2012:2-4). Malaysia offers an array of very attractive incentives to investors wanting to invest within the SEZs and these incentives lure investors to the SEZs. Another remarkable benefit of the SEZs in Malaysia is the skills development centres that have been set up throughout the country (Chai \& Im, 2009:12).

\subsection{Special economic zones in Indonesia}

Similar to Malaysia and South Africa, the economic activity of Indonesia was disadvantaged owing to political reasons. For around 350 years, Indonesia was a Dutch colony and became independent only in 1945. This was after it had suffered under Japanese rule for three years, when there was a scarcity of food, clothing and medicine and labour conditions were tough (IndonesiaInvestments, not dated).

In 2011, the President of Indonesia stated that within the next decade Indonesia would be among the top 10 countries in the world with one of the strongest economies (Abidin, 2014:9). Indonesia is part of the Group of Twenty: the largest and most advanced developing economies in the world, 
which together account for more than $75 \%$ of global trade and two-thirds of the world's population $(G 20,2014)$.

One of the most important economic zones in Indonesia is the island, Batam. It has attracted substantial amounts of investment and also contributed significantly to the success of Indonesia's industrialisation strategy (Sivananthiran, 2009:1). It was established in the 1960s, purely as a logistic centre for storage and oil and gas distribution (Aritenang, 2009:97). Because of the island's prime and strategic location, the development of Batam Island began in 1973 and the government of Indonesia proclaimed it as an industrial zone. This led to the establishment of the region's administrator, the Batam Industrial Development Agency (BIDA) (Aritenang, 2009:97). By the end of the 1970s, a plan had been developed to turn the Batam Island into Indonesia's main commercial, industrial and tourism centre (Kam \& Kee, 2009:3).

The establishment of Export Processing Zones (EPZs) in May 1986 was a major step towards encouraging exports because the EPZs allowed for the exemption of import and export duties, as well as a drawback scheme that allowed export-oriented companies to acquire inputs, whether locally produced or imported, at international prices. The establishment of EPZs was a crucial factor in encouraging exports by local and foreign companies (Sivananthiran, 2009:3).

The scope of regional development expanded beyond the Batam Island to other provinces and, in 1990, Bintan became a prime investment destination for investment in tourism, fishing, industry and agriculture because of Bintan's accessibility to major international shipping routes (Kam \& Kee, 2009:4).

Batam's population increased from 43000 in 1983 to 724315 at the end of 2007, as well as an increase in the workforce in Batam from 16336 in 1990 to 243857 at the end of 2007. Total investment in Batam alone totalled US\$13.08 billion in 2007, of which $36 \%$ was received from foreign investors (Kam \& Kee, 2009:15). Not only has the establishment of the economic zones in Indonesia led to job creation and an increase in investments, but Batam has also been acknowledged, and ranked second after Bali, as a major tourism destination (Aritenang, 2009:98).

The industrial development of Indonesia since the 1960s has taken various forms, from industrial zones to EPZs, free trade zones and, most recently, the establishment of SEZs. The municipalities played an active role in the SEZs in Indonesia. The municipalities not only play a role in the regional Zone Councils but also offer local incentives to the SEZs. The involvement of the private sector in the SEZs in Indonesia is also notable as some countries only allow for non-private involvement.

It can thus be seen that Malaysia and Indonesia have both been successful in the implementation of their SEZ Programmes and South Africa can learn from their achievements.

\section{METHOD}

The comparison of South Africa, Malaysia and Indonesia's SEZ Programmes was conducted by reviewing available secondary data: the relevant legislation, government policies, commentaries and other articles available in English regarding this topic. This comparative analysis is descriptive in nature as it will be describing the key aspects of the SEZ Programme of each selected country.

In addition to factors already mentioned, TABLE 1 will identify some contextual characteristics of these three countries on which the research was performed: 
TABLE 1: Contextual characteristics of South Africa, Malaysia and Indonesia

\begin{tabular}{|c|c|c|c|}
\hline Factor & South Africa & Malaysia & Indonesia \\
\hline $\begin{array}{l}\text { Development of state } \\
\text { (The International } \\
\text { Statistics Institute: } \\
\text { not dated) }\end{array}$ & Developing country & Developing country & Developing country \\
\hline $\begin{array}{l}\text { GDP (millions of US } \\
\text { Dollars, 2012) (World } \\
\text { Bank, 2014) }\end{array}$ & 350630 & 313159 & 868346 \\
\hline $\begin{array}{l}\text { GDP (ranking, 2012) } \\
\text { (World Bank, 2014) }\end{array}$ & 33 & 35 & 16 \\
\hline $\begin{array}{l}\text { GDP growth \% in } 2013 \\
\text { (World Bank, 2015a) }\end{array}$ & $2.2 \%$ & $4.7 \%$ & $5.8 \%$ \\
\hline $\begin{array}{l}\text { GINI index in } 2011 \\
\text { (World Bank, 2015a) }\end{array}$ & 65 & Not available & 38.1 \\
\hline $\begin{array}{l}\text { Unemployment rate } \\
\text { (2014) (Trading } \\
\text { Economics, 2014) }\end{array}$ & $25.4 \%$ & $2.7 \%$ & $5.94 \%$ \\
\hline $\begin{array}{l}\text { Income level Upper } \\
\text { middle income (World } \\
\text { Bank, 2015b) }\end{array}$ & Upper middle income & Upper middle income & $\begin{array}{l}\text { Lower middle } \\
\text { income }\end{array}$ \\
\hline Natural resources & $\begin{array}{l}\text { Rich (Encyclopaedia } \\
\text { Britannica, 2015b) }\end{array}$ & $\begin{array}{l}\text { Rich (Encyclopaedia } \\
\text { Britannica, 2015a) } \\
\text { (although Penang } \\
\text { itself does not have } \\
\text { natural resources) }\end{array}$ & Rich (BKPM, 2015) \\
\hline
\end{tabular}

Source: Authors' analysis

What can be deduced from the above table is that there are some similarities between South Africa and Malaysia regarding income levels (upper middle income group). All three countries are still developing countries and all are rich in natural resources. South Africa is striving to reduce unemployment and therefore, because Indonesia and Malaysia have such low unemployment rates and a good gross domestic product, partly because of the successful implementation of their SEZ programmes, South Africa's SEZ programme was compared to these countries' SEZ programmes to determine what factors have not been considered in the drafting of the SEZ programme.

South African leaders have been impressed by the economic growth that Malaysia achieved in overcoming colonialism and poverty and said that South Africa has a lot to learn from them, specifically regarding affirmative action. It was thus decided by these leaders that South Africa's affirmative action plan (Black Economic Empowerment) would be based on the successful plan of Malaysia (Ratuva, 2013:238) and was implemented in 1998. Affirmative action is an action used to get rid of imbalances between gender and race in the workplace (Archibong \& Adejumo, 2013:15). As South African legislation has previously been based on that of Malaysia, Malaysia was selected as a country for this comparative study. 
There are many incentives available in South Africa to assist with economic growth, job creation, exports and local and foreign investments. However, this study focuses only on the new SEZ programme of South Africa as a means of growing the economy.

This study will focus only on comparing the new SEZ Programme in South Africa with the SEZ programmes of Malaysia and Indonesia and not those of any other countries.

\section{RESULTS}

\subsection{Comparison of special economic zones in South Africa, Malaysia and Indonesia}

This section compares the key aspects of the design of the new SEZ Programme in South Africa with those of SEZ Programmes in Malaysia and Indonesia. Recommendations are made of how the South African government might improve the design of the SEZ Programme in South Africa.

A comparison of the SEZ programmes in South Africa, Malaysia and Indonesia is set out in TABLE 2.

TABLE 2: Comparison of the key aspects of Special Economic Zones in South Africa, Malaysia and Indonesia

\begin{tabular}{|c|c|c|c|}
\hline & South Africa SEZs & Malaysia SEZs & Indonesia SEZs \\
\hline $\begin{array}{l}\frac{0}{\frac{2}{5}} \\
\frac{n}{2} \\
\frac{c}{3} \\
00\end{array}$ & $\begin{array}{l}\text { SEZs can be owned by: } \\
\text { The government (national } \\
\text { government, provincial } \\
\text { government, municipality, } \\
\text { public entity or a municipal } \\
\text { entity); or } \\
\text { Public-Private-Partnership } \\
\text { arrangement between the } \\
\text { private sector and the } \\
\text { government (Section } 23 \text { of } \\
\text { the SEZ Act). }\end{array}$ & $\begin{array}{l}\text { As no information could be } \\
\text { found on the ownership of } \\
\text { the SEZs by the private } \\
\text { sector it is assumed that } \\
\text { SEZs in Malaysia are } \\
\text { government-owned. }\end{array}$ & $\begin{array}{l}\text { SEZs can be owned by: } \\
\text { The government (provincial } \\
\text { administration, local } \\
\text { administration, or government } \\
\text { institutions); or } \\
\text { Business entities } \\
\text { (cooperatives, state-owned } \\
\text { companies, regional } \\
\text { government companies, } \\
\text { private companies or joint } \\
\text { ventures between private } \\
\text { entities and the government) } \\
\text { (article } 30 \text { to } 34 \text { of the } \\
\text { Regulations regarding the } \\
\text { designation of SEZs ( } 2 / 2011 \text { ) } \\
\text { (hereinafter referred to as the } \\
\text { Regulations)). }\end{array}$ \\
\hline 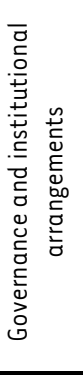 & $\begin{array}{l}\text { SEZs in South Africa are } \\
\text { governed by the following } \\
\text { parties: } \\
\text { Minister of Trade and } \\
\text { Industry may designate an } \\
\text { area as an SEZ (section } 5 \\
\text { and } 6 \text { of the SEZ Act); } \\
\text { The SEZ Advisory Board } \\
\text { reports to the Minister of } \\
\text { Trade and Industry and will }\end{array}$ & $\begin{array}{l}\text { SEZs in Malaysia are } \\
\text { governed by the following } \\
\text { parties: } \\
\text { Minister of Finance may } \\
\text { designate an area as a FIZ } \\
\text { or free commercial zone } \\
\text { (FCZ) (section 3(1) of the } \\
\text { Free Zones Act ( } 438 / 1990) \text { ); } \\
\text { A Free Zone Authority } \\
\text { reports to the Minister of }\end{array}$ & $\begin{array}{l}\text { SEZs in Indonesia are governed } \\
\text { by the following parties: } \\
\text { President of Indonesia } \\
\text { provides the final approval to } \\
\text { designate an area as an SEZ } \\
\text { (article } 7 \text { of the SEZ Law } \\
(39 / 2009) \text { ); } \\
\text { The National Council reports } \\
\text { to the President and oversees } \\
\text { all SEZs and consists of }\end{array}$ \\
\hline
\end{tabular}




\begin{tabular}{|c|c|c|c|}
\hline & South Africa SEZs & Malaysia SEZs & Indonesia SEZs \\
\hline & $\begin{array}{l}\text { consist of representatives } \\
\text { from the public sector, such } \\
\text { as different government } \\
\text { authorities, as well as } \\
\text { representatives from the } \\
\text { private sector. No person } \\
\text { below the position of } \\
\text { Director-General may be } \\
\text { appointed to the SEZ } \\
\text { Advisory Board (Section } 7 \text { of } \\
\text { the SEZ Act). } \\
\text { A licensee or owner of an SEZ } \\
\text { is a government or a Public- } \\
\text { Private-Partnership that is } \\
\text { in charge of the design, } \\
\text { development and } \\
\text { implementation of an SEZ } \\
\text { (DTI, 2013:3); and } \\
\text { The licensee will appoint an } \\
\text { operator to administer and } \\
\text { operate the SEZ. The SEZ } \\
\text { operator manages the day- } \\
\text { to-day operations of the } \\
\text { SEZs and ensures that the } \\
\text { infrastructure is maintained } \\
\text { (DTI, 2012: } 20 \text { ). }\end{array}$ & $\begin{array}{l}\text { Finance and is a legal entity } \\
\text { or statutory body } \\
\text { incorporated under a } \\
\text { federal law or any } \\
\text { department of the } \\
\text { Malaysian Government or of } \\
\text { any State and operates, } \\
\text { maintains and administers } \\
\text { the SEZ (section 3(2) of the } \\
\text { Free Zones Act); } \\
\text { A Free Zone operator to } \\
\text { maintain appropriate } \\
\text { records of all activities that } \\
\text { take place within the zone } \\
\text { premises (section } 5 \text { of the } \\
\text { Free Zones Regulations } \\
\text { (1991)); and } \\
\text { A Customs Department is } \\
\text { established in the SEZs to } \\
\text { regulate the movement of } \\
\text { goods at the various access } \\
\text { points (Chai \& Im, 2009:6). }\end{array}$ & $\begin{array}{l}\text { Ministers at national } \\
\text { government level and heads of } \\
\text { non-governmental agencies } \\
\text { (article } 15 \text { and } 16 \text { of the SEZ } \\
\text { Law); } \\
\text { A Zone Council is appointed in } \\
\text { each province or region in } \\
\text { which an area is designated as } \\
\text { an SEZ and shall include } \\
\text { various government } \\
\text { representatives of the } \\
\text { provinces (article } 19 \text { of the } \\
\text { SEZ Law); } \\
\text { A Zone Administrator is } \\
\text { appointed in each SEZ and } \\
\text { assists the Zone Council with } \\
\text { the administration of the SEZs } \\
\text { (article } 21 \text { of the SEZ Law); } \\
\text { and } \\
\text { Business entities manage the } \\
\text { SEZs (article } 26 \text { of the S\&Z } \\
\text { Law). }\end{array}$ \\
\hline 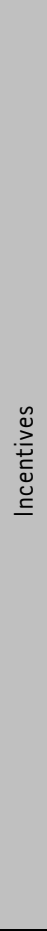 & $\begin{array}{l}\text { Incentives offered in South } \\
\text { Africa to investors and } \\
\text { entities operating within the } \\
\text { SEZs include: } \\
\text { Corporate tax rate of } 15 \% \\
\text { (section } 12 R(2) \text { of the } \\
\text { Income Tax Act (58/1962)); } \\
\text { Building allowance } \\
\text { deduction of } 10 \% \text { (section } \\
12 S(2) \text { of the Income Tax } \\
\text { Act); } \\
\text { Duty-free and VAT } \\
\text { exemption (Africa Institute } \\
\text { of South Africa \& DTI, } \\
2013: 39 \text { ); } \\
\text { Employment tax incentives } \\
\text { (Employment Tax Incentive } \\
\text { Act (26/2013)); and } \\
\text { Provision of infrastructure } \\
\text { (Africa Institute of South } \\
\text { Africa \& DTI, 2013:39). }\end{array}$ & $\begin{array}{l}\text { Incentives offered in } \\
\text { Malaysia to investors and } \\
\text { entities operating within } \\
\text { the SEZs include: } \\
\text { Pioneer status partial } \\
\text { exemption of } 70 \% \text { on the } \\
\text { payment of income tax for } \\
\text { five years. Companies may } \\
\text { also qualify for pioneer plus } \\
\text { status and receive a } 100 \% \\
\text { exemption on the payment } \\
\text { of income tax for five or } 10 \\
\text { years (Malaysia Investment } \\
\text { Development Authority } \\
\text { (MIDA), } 2013: 19-20 \text { ); } \\
\text { Investment tax allowance to } \\
\text { deduct an allowance of } 60 \% \\
\text { of its investment acquired } \\
\text { against } 70 \% \text { of the } \\
\text { company's income for each } \\
\text { year of assessment. } \\
\text { Companies may also qualify } \\
\text { for an investment tax } \\
\text { allowance of up to } 100 \% \text { of } \\
\text { its investment acquired to } \\
\text { be deducted against } 100 \%\end{array}$ & $\begin{array}{l}\text { Incentives offered in } \\
\text { Indonesia to investors and } \\
\text { entities operating within the } \\
\text { SEZs include: } \\
\text { Postponement of import duty } \\
\text { and import income tax is not } \\
\text { levied; } \\
\text { Exemption of excise duty; } \\
\text { Non-collection of VAT and } \\
\text { sales tax for taxable goods } \\
\text { and luxury transactions; } \\
\text { Property tax reduction; } \\
\text { Tax incentives, such as } \\
\text { reduced tax rates or } \\
\text { exemption of local taxes, may } \\
\text { be offered at local } \\
\text { municipality level; and } \\
\text { Provision of infrastructure } \\
\text { (article } 30 \text { to } 36 \text { of the SEZ } \\
\text { Law). }\end{array}$ \\
\hline
\end{tabular}




\begin{tabular}{|c|c|c|c|}
\hline & South Africa SEZs & Malaysia SEZs & Indonesia SEZs \\
\hline & & $\begin{array}{l}\text { of the company's income } \\
\text { (MIDA, 2013:20) }\end{array}$ & \\
\hline & & $\begin{array}{l}\text { Reinvestment allowance of } \\
60 \% \text { of capital expenditure } \\
\text { may be deducted from } 70 \% \\
\text { of the company's income } \\
\text { (MIDA, 2013:25); }\end{array}$ & \\
\hline & & $\begin{array}{l}\text { Free of customs duty, excise } \\
\text { duty, sales and service tax } \\
\text { (Section } 4 \text { of the Free Zones } \\
\text { Act); }\end{array}$ & \\
\hline & & $\begin{array}{l}\text { Skills training (Wahyuni et } \\
\text { al., 2012:7); and }\end{array}$ & \\
\hline & & $\begin{array}{l}\text { Provision of infrastructure: } \\
\text { roads, proper drainage and } \\
\text { telecom systems (Chai \& Im, } \\
\text { 2009:11). }\end{array}$ & \\
\hline \multirow{3}{*}{ 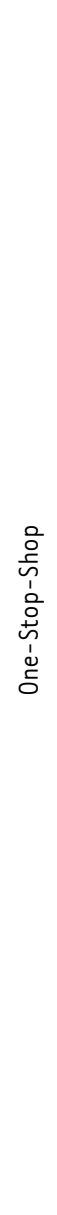 } & $\begin{array}{l}\text { The following One-Stop- } \\
\text { Shop models are planned: }\end{array}$ & $\begin{array}{l}\text { MIDA is a legal entity and } \\
\text { has offices all across } \\
\text { Malaysia. }\end{array}$ & $\begin{array}{l}\text { Indonesia's One-Stop-Shop is } \\
\text { referred to as the "one door } \\
\text { integrated services facility". }\end{array}$ \\
\hline & $\begin{array}{l}\text { Short-term model: A One- } \\
\text { Stop-Shop will be } \\
\text { established in each SEZ and } \\
\text { will be managed by the SEZ } \\
\text { operator. Investors wanting } \\
\text { to operate within an SEZ will } \\
\text { lodge various applications } \\
\text { at a single location within } \\
\text { the SEZ and the designated } \\
\text { officers at the One-Stop- } \\
\text { Shop will liaise with the } \\
\text { various government } \\
\text { departments and agencies in } \\
\text { order to process the } \\
\text { applications. The investors } \\
\text { will receive the various } \\
\text { licences for which they have } \\
\text { applied from the single One- } \\
\text { Stop-Shop (Africa Institute } \\
\text { of South Africa \& DTI, } \\
2013: 12 \text { ). }\end{array}$ & $\begin{array}{l}\text { MIDA established a } \\
\text { committee that consists of } \\
\text { representatives from } \\
\text { various government } \\
\text { departments. Applications } \\
\text { for licences from the } \\
\text { various government } \\
\text { departments can be } \\
\text { downloaded online from the } \\
\text { MIDA website (MIDA, 2012). }\end{array}$ & $\begin{array}{l}\text { Each Zone Administrator } \\
\text { manages and operates its own } \\
\text { One-Stop-Shop facility within } \\
\text { the SEZs. The Zone } \\
\text { Administrators have } \\
\text { delegated authority from the } \\
\text { central government, and } \\
\text { provincial and local } \\
\text { government authorities for } \\
\text { granting business permits and } \\
\text { other licences to companies } \\
\text { wanting to operate within an } \\
\text { SEZ (article } 23 \text { and } 24 \text { of the } \\
\text { SEZ Law). }\end{array}$ \\
\hline & $\begin{array}{l}\text { Long-term model: An } \\
\text { electronic or online facility } \\
\text { will be developed for the } \\
\text { completion of all relevant } \\
\text { applications for registration, } \\
\text { licences and permits and will } \\
\text { be processed online by the } \\
\text { relevant authorities (Africa } \\
\text { Institute of South Africa \& } \\
\text { DTI, 2013:12-13). }\end{array}$ & & \\
\hline
\end{tabular}




\begin{tabular}{|c|c|c|c|}
\hline & South Africa SEZs & Malaysia SEZs & Indonesia SEZs \\
\hline 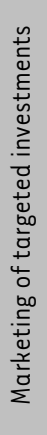 & $\begin{array}{l}\text { The establishment of a } \\
\text { National Marketing Strategy } \\
\text { which is run by the SEZ } \\
\text { Advisory Board for the } \\
\text { promotion of the SEZs (DTI, } \\
2012: 25 \text { ). } \\
\text { The IDZ Programme lacked } \\
\text { an appropriate marketing } \\
\text { strategy capable of } \\
\text { attracting local and foreign } \\
\text { investments to the IDZs (DTI, } \\
\text { 2013:12). }\end{array}$ & $\begin{array}{l}\text { MIDA is a legal entity and is } \\
\text { the government's prime } \\
\text { agency in Malaysia } \\
\text { responsible for the } \\
\text { coordination and marketing } \\
\text { of the services and } \\
\text { manufacturing industries } \\
\text { and SEZs (Wahyuni et al., } \\
2012: 12 \text { ). }\end{array}$ & $\begin{array}{l}\text { Badan Koordinasi Penanaman } \\
\text { Modal (BKPM) is the prime } \\
\text { investment administration } \\
\text { and promotion agency in } \\
\text { Indonesia and the chairman } \\
\text { reports directly to the } \\
\text { President and is a member of } \\
\text { the National Council } \\
\text { (Organisation for Economic } \\
\text { Development, 2010:88). }\end{array}$ \\
\hline 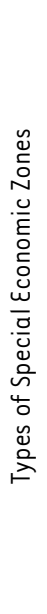 & $\begin{array}{l}\text { Types of SEZs to be } \\
\text { established may include: } \\
\text { A free port; } \\
\text { A free trade zone; } \\
\text { A sector development zone; } \\
\text { and } \\
\text { An IDZ (Section } 24 \text { of the SEZ } \\
\text { Act). } \\
\text { The IDZ Programme only } \\
\text { allowed for one category of } \\
\text { an SEZ to be implemented, } \\
\text { namely an IDZ, which meant } \\
\text { that only areas close to a } \\
\text { seaport or international } \\
\text { airport could be designated } \\
\text { as IDZs (DTI, 2012:17). }\end{array}$ & $\begin{array}{l}\text { Licensed manufacturing } \\
\text { warehouse (LMW) facilities } \\
\text { may be set-up in areas } \\
\text { where it is impossible to } \\
\text { set-up FIZs. LMW facilities } \\
\text { are similar to } \\
\text { manufacturing facilities } \\
\text { operating in FIZs and also } \\
\text { enjoy duty-free imports } \\
\text { (MIDA, 2013:162). }\end{array}$ & $\begin{array}{l}\text { Types of SEZs to be } \\
\text { established may include: } \\
\text { An EPZ; } \\
\text { A logistic zone; } \\
\text { A manufacturing zone; } \\
\text { A technology zone; and } \\
\text { A tourism zone (article } 3 \text { of } \\
\text { the Regulations). }\end{array}$ \\
\hline 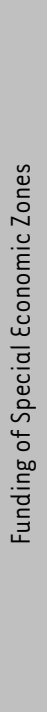 & $\begin{array}{l}\text { An SEZ Fund will be } \\
\text { established and } \\
\text { administered by the DTI. An } \\
\text { adjudication committee will } \\
\text { be established and will be } \\
\text { responsible for evaluating } \\
\text { applications for funding } \\
\text { from the SEZs. The SEZ Fund } \\
\text { will be used to finance } \\
\text { approved projects, such as } \\
\text { the servicing of sites, } \\
\text { business development of the } \\
\text { SEZs and the provision of } \\
\text { bulk infrastructure (DTI, } \\
2013: 8 \text { ). } \\
\text { Where there are Public- } \\
\text { Private-Partnerships it is } \\
\text { assumed that funding will } \\
\text { also come from the private } \\
\text { sector. }\end{array}$ & $\begin{array}{l}\text { The Free Zones Act and Free } \\
\text { Zones Regulations do not } \\
\text { clearly indicate how the } \\
\text { SEZs are funded. It is, } \\
\text { however, indicated that the } \\
\text { Free Zones Authority must } \\
\text { submit a budget to the } \\
\text { Minister of Finance for } \\
\text { approval (section 13(4) of } \\
\text { the Free Zones } \\
\text { Regulations). }\end{array}$ & $\begin{array}{l}\text { The development, } \\
\text { maintenance and } \\
\text { infrastructure within SEZs may } \\
\text { be funded by the: } \\
\text { State or regional budget; } \\
\text { Central, national, provincial or } \\
\text { regional government; } \\
\text { Local administrations; } \\
\text { Business entities which } \\
\text { include private companies; } \\
\text { Co-operation between the } \\
\text { government and business } \\
\text { entities; or } \\
\text { Other finance sources (article } \\
13 \text { and } 25 \text { of the SEZ Law, } \\
\text { article } 31 \text { of the Regulations.) }\end{array}$ \\
\hline
\end{tabular}

Source: Authors' analysis 


\subsection{Summary of comparative study}

\subsubsection{Ownership}

The SEZ Act in South Africa does not allow for solely privately owned SEZs because it stipulates that SEZs should be owned by the government or by a Public-Private-Partnership arrangement. It was not clear who may own SEZs in Malaysia, although the assumption from other information is that all SEZs are government-owned. Indonesia allows for government or fully private ownership of SEZs. A trend in SEZ development globally over the past 15 years has been the increasing importance of economic zones that are owned, developed or operated by the private sector (FIAS, 2008:2). International best practice has shown that SEZs owned and managed by the private sector, rather than solely by the public sector, are the most successful in the world (FIAS, 2008:51). However, formal Public-Private-Partnerships have also become popular around the world as both the government and the private sector have important roles to play in SEZ development (FIAS, 2008:2-4).

Although Public-Private-Partnerships are becoming very popular, it is recommended that the South African government should consider allowing for purely privately owned SEZs, as indicated by international best practice.

\subsubsection{Governance and institutional arrangements}

From the data it is evident that in South Africa and Malaysia, the ministries of the countries are the highest authorities in the SEZ structure, whereas in Indonesia, the President has final approval of SEZ zones and has to be reported to. Various international best practice benchmarks by FIAS (2008:56-57), Centre for Development and Enterprise (2012:4) and Farole (2011:152) mention that the best practice towards ensuring the success of SEZs is the involvement of the highest level of authority in the governance of SEZs. An effective institutional framework for SEZs involves establishing an independent board consisting of Ministers of key government sectors, as well as private sector representatives who report to the highest office in government, namely the President (FIAS, 2008:56-57).

The S\&Z Act in South Africa allows for private sector representatives on the SEZ Advisory Board as recommended by international best practice and the SEZ Advisory Board reports to the Minister of Trade and Industry. Although the SEZ Act allows for members on the Advisory Board who hold the post of a Director-General, it is recommended that the South African government considers appointing Ministers from various key government sectors to the Advisory Board and that the Advisory Board should report to the President, as suggested by international best practice. By these means decisions can be speedily made and those decisions should be final and should be swiftly implemented by government officials. It is also recommended that the South African government should consider providing for customs support in each SEZ to ensure that the movement of goods in and out of the SEZs is regulated continuously.

\subsubsection{Incentives}

South Africa, Malaysia and Indonesia each offers attractive incentives to investors and entities operating within the SEZs, which is also a best practice as determined by the FIAS (2008:12). Many of the incentives offered in the various countries differ, but most of these countries offer some form of tax holiday together with the exemption of certain taxes and other non-tax benefits, such as the exemption of customs duty and the provision of infrastructure. 
South Africa provides an attractive corporate tax and building tax allowance, as well as an employment tax incentive to investors and entities operating within the SEZs. Incentives provided in Malaysia and Indonesia, which are not provided to investors and entities operating within SEZs in South Africa, include excise duty exemption, pioneer status exemption, investment tax allowance deduction, reinvestment allowance, property tax reduction, skills training centres for employees and tax incentives offered at local municipality level.

Although the incentives offered to investors and entities operating within SEZs in South Africa are attractive, it is recommended that the South African government consider expanding the provision of incentives by taking note of those provided by Malaysia and Indonesia to investors and entities operating within the SEZs.

\subsubsection{One-Stop-Shop}

South Africa will establish a One-Stop-Shop in each SEZ and the long-term model allows for an online facility through which all registration, licensing and permits will be done. Malaysia and Indonesia have 0 ne-Stop-Shops through which the administration is controlled. Currently, a key trend throughout the world is the establishment of One-Stop-Shops by means of legislation, which appoints a governing body with the authority over other government agencies to consolidate and expedite government approvals (FIAS, 2008:57). South Africa, Malaysia and Indonesia each offer various forms of One-Stop-Shops so that investors can apply for various licences at a single location or a single authority and do not have to approach all of the various government agencies for approval.

The establishment of an online facility will be beneficial, as investors will not have to approach the various One-Stop-Shops within the SEZs, and all applications can be lodged online. It is recommended that the South African government, as in Indonesia, considers providing the officials within the One-Stop-Shops with the authority to provide licences to investors in order to hasten the approval process since there will be no need for officials at the One-Stop-Shops to liaise with the various government authorities outside the SEZs. It is also recommended that when the process of developing the proposed long-term model for the One-Stop-Shops commences, the South African government should consider establishing a single authority or legal entity in South Africa, such as MIDA, to operate the online facility.

\subsubsection{Marketing of targeted investments}

South Africa will establish a national marketing strategy for promotion purposes. Malaysia and Indonesia both have one entity responsible for the marketing of all SEZs. International best practice has indicated that SEZs are most successful when effective investment promotion agencies are established within countries whose main goal is to attract investment (Centre for Development and Enterprise, 2012:47). MIDA in Malaysia and BKPM in Indonesia are such promotion agencies. The SEZ Act in South Africa makes provision for the establishment of a National Marketing Strategy to be run by the SEZ Advisory Board for the promotion of the SEZs. This is a strategy and not an agency.

It is recommended that the South African government should consider the establishment of an investment promotion agency, such as MIDA, to promote the SEZs and that one of the representatives on the SEZ Advisory Board should be a member of the promotion agency, as in Indonesia. The reason for the establishment of a promotion agency as a legal entity rather than a 
national marketing strategy is that the members of the promotion agency will be dedicated solely to promoting the SEZs and will not have other duties.

\subsubsection{Types of special economic zones}

South Africa, Malaysia and Indonesia each offers various categories of SEZs that may be established. South Africa offers a wide range of categories of SEZs which may be established and SEZs in South Africa are on par with categories of SEZs offered in Malaysia and Indonesia. However, it is recommended that the South African government should not limit the types of SEZs to be stipulated in the SEZ Act. This would ensure that, if necessary, additional types of SEZs could be established.

\subsubsection{Funding of special economic zones}

The funding of SEZ development and maintenance can be linked back to the ownership of the SEZs. International best practice has indicated that the key factor behind the growth of private sector ownership of SEZs is that they can be profitably operated by the private sector with private sector funding and that the burden which SEZs place on government resources can be significantly reduced (FIAS, 2008:2). Private sector funding is also necessary as there is generally a lack of funding for new government SEZ development (FIAS, 2008:18).

In South Africa, an SEZ Fund will be established by the government to ensure that funding is available when needed and will be administered by the DTI. Where there are Public-PrivatePartnerships, it is assumed that funding will also come from the private sector, although this is not indicated in the SEZ Act. The SEZ Law in Indonesia clearly indicates that funding for the development and management of SEZs may come from various sources. Funding of the SEZs in Indonesia is not limited to a single fund as in South Africa, and if the private sector owns the SEZ then it will be responsible for the funding of that SEZ.

From the points mentioned above, the following recommendations are made for consideration to be inserted into the legislation:

\section{TABLE 3: Recommendations to improve the South African S\&Z Programme design}

The appointment of government Ministers from key government sectors to the Advisory Board, who reports to the President.

The provision of customs support in each SEZ.

Allowing for sole ownership of the SEZs by the private sector.

Expanding the provision of incentives by referring to the incentives provided by Malaysia and Indonesia, including excise duty exemption, pioneer status exemption, investment tax allowance deduction, reinvestment allowance, property tax reduction, skills training centres for employees, as well as allowing municipalities to offer various incentives.

Providing officials within the One-Stop-Shops with the authority to offer licences to investors in order to speed up the approval process. It is also recommended that when the process to develop the proposed long-term model for the One-Stop-Shop commences, the South African government should consider establishing a single authority or legal entity in South Africa to operate the online facility. 
Allowing for a provision in the SEZ Act which does not limit the categories of SEZs that could be established.

The establishment of an investment promotion agency which is dedicated to promoting the SEZs.

The SEZ Act in South Africa should allow for various forms of funding, from various sources and not only from the SEZ Fund.

Source: Authors' analysis

\section{CONCLUSION}

The main purpose of this study was to compare the key aspects of the new SEZ Programme in South Africa to those of Malaysia and Indonesia, since both these countries have successfully established SEZs, which have contributed to the development of these countries. The data in TABLE 2 indicates that the new SEZ Programme in South Africa is on par with the SEZ programmes in Malaysia and Indonesia. The ideas of the One-Stop-Shop, type of SEZs allowed for and the marketing strategy are similar in all three countries. The incentives offered are also lucrative in all countries, although some of the specific incentives are different. The governance, ownership and funding differs slightly amongst the countries: Indonesia has the President as the highest power governing the SEZs and allows for fully private entities to own and fund SEZs.

Since ultimately the real question is the impacts SEZs have on economic development, future research should monitor the process of the programme in South Africa over time. Although SEZs may assist in increasing investment, employment and exports, they should not be viewed as the main instrument for growing South Africa's economy. Further studies could be done to determine what other factors could influence the economy. "Strength and growth come only through continuous effort and struggle" (Hill, not dated).

\section{LIST OF REFERENCES}

Abidin, J. (2014). Trade Union Right Policies: A comparative paper between India and Indonesia. Available: http://www.academia.edu/4156373/Trade_Union_ Right_Policies_Comparative_Study_of_India_and_Indonesia. (Accessed 26 July 2014).

Africa Institute of South Africa \& Department of Trade and Industry. (2013). Proposed special economic zones: One-Stop-Shop model for South Africa. South Africa: Africa Institute of South Africa.

Aggarwal, A. (2007). Impact of Special Economic Zones on Employment, Poverty and Human Development. Available: http://www.democraciaycooperacion.net/IMG/pdf/lworking_paper_194.pdf. (Accessed 26 August 2015).

Archibong, U \& Adejumo, A. (2013). Affirmative action in South Africa: Are we creating new casualties? Journal of Psychological Issues in Organizational Culture, Volume 3, Number S1, 2013: 1427. Available: http://0-onlinelibrary.wiley.com.innopac.up.ac.za/doi/10.1002/jpoc.21073/epdf. (Accessed 17 June 2015) 
Aritenang, A.F. (2009). A comparative paper on free trade zone: Development through spatial economic concentration. Available: http://www.South Africappk.itb.ac.id/jpwk/wpcontent/uploads/2014/01/Microsoft-Word-Adiwan-F.pdf. (Accessed 26 July 2014).

BKPM, Indonesia Investment Co-ordinating Body. (2015). Invest in remarkable Indonesia. Available: http://www.bkpm.go.id/contents/general/7/natural-resources\#.VMCrAUeUcuc. (Accessed 22 January 2015).

Bräutigam, D. \& Xiaoyang, T. (2011). African Shenzhen: China's Special Economic Zones in Africa. Journal of Modern African Studies, 49(1), 27-54. Cambridge University Press. Available: http://urban-africa-china.angonet.org/sites/default/files/resource_files/african-shenzhenchina-s-special-economic-zones-in-africa.pdf. (Accessed 26 August 2015).

Centre for Development and Enterprise. (2012). Special economic zones: Lessons for South Africa from international evidence and local experience. Available:

http://www.cde.org.za/images/pdf/SEZs\%20full\%20report.pdf (Accessed 14 February 2014).

Chai, Y.T. \& Im, 0.C. (2009). The development of Free Industrial Zones: The Malaysian experience. Available: http://info.worldbank.org/etools/docs/library/251665/

Yeow 20 Teck\%20Chai\%20and\%200oi\%20Chooi\%201m\%20-\%20The\%20Development $\% 20$ of\%20Free\%20Industrial\%20Zones\%96The\%20Malaysian\%20Experience.pdf. (Accessed 3 June 2014).

Chiang, C.H. (2011). Penang Economic Outlook. Available:

http://penanginstitute.org/v3/files/14_PEM_OUTLOOK_FA.pdf. Accessed 8 June 2014.

Deloitte. (2013). Gearing up for special economic zones. Johannesburg: Deloitte.

Department of Research and Information. (2013). Economic overview: Recent developments in the global and South African economies. Available: http://www.idc.co.za/reports/South Africa_Economic_Overview_November_2013.pdf. (Accessed 2 February 2014).

Department of Trade and Industry. (2013). Proposed special economic zones governance framework. Pretoria: Government Printer.

Department of Trade and Industry. (2012). Policy on the development of special economic zones in South Africa. Available: http://www.dti.gov.za/DownloadFileAction?id=830 (Accessed 21 January 2015).

Encyclopaedia Britannica. (2015a). Malaysia. Available: http://global.britannica.com/EBchecked/topic/359754/Malaysia/52536/Resources-and-power. [Accessed: 2015-01-22].

Encyclopaedia Britannica. (2015b). South Africa. Available: http://global.britannica.com/EBchecked/topic/555568/South-Africa/44033/Resources-and-power. (Accessed 22 January 2015).

Engman, M., Onnodera, 0 \& Pinali, ع. (2007). Export Processing Zones: Past and future role in trade and development: OECD trade policy working papers no. 53. Available:

http://search.oecd.org/officialdocuments/displaydocumentpdf/?cote=TD/TC IWP(2006)39/FINAL\&docLanguage= $\varepsilon$ n. (Accessed 20 March 2014).

Farole, T. (n.d.). Special Economic Zones: Performance, Policy and Practice- With a Focus on SubSaharan Africa. Available: http://led.co.za/sites/default/files/cabinet/orgnameraw/document/2013/specialeconomiczones_sep2010.pdf (Accessed 26 August 2015). 
Farole, T. (2011). Special economic zones in Africa: Comparing performance and learning from global experience. Available: https://openknowledge.worldbank.org/ handle /10986/2268. (Accessed 28 January 2014).

Foreign Investment Advisory Service. (2008). Special economic zones: Performance, lessons learned and implications for zone development. Available:

https://www.wbginvestmentclimate.org/uploads/SEZs\%20-\%20Performance, \%20Lessons \%20Learned\%20and\%20Implications\%20for\%20Zone\%20Development.pdf. (Accessed 28 January 2014).

G20. (2014). G20 members. Available: https://www.g20.org/about_g20/g20_members. (Accessed 26 July 2014).

Hill, N. (N.D.). Brainy Puote. Available: http://www.brainyquote.com/quotes/keywords/growth.html. (Accessed 22 January 2015).

Indonesia. President of the Republic of Indonesia. (2009). Law of the Republic of Indonesia regarding Special Economic Zones, No. 39 of 2009. 1-22. Available:

http://www.flevin.com/id/Igso/translations/Laws/Law\%20No.\%2039\%20of\%202009

\%20on\%20Special\%20Economic\%20Zones\%20(MoF).pdf. (Accessed 23 July 2014).

Indonesia. President of the Republic of Indonesia. (2011). Regulations of the Government of the Republic of Indonesia regarding the designation of Special Economic Zones, No. 2 of 2011. 1-84. Available: http://www.flevin.com/id/lgso/

translations/Laws/Law\%20No.\%2039\%20 of\% $202009 \% 20$ on\%20Special\%20Economic\%20Zones\%20(M oF).pdf. (Accessed 23 July 2014).

Indonesia-investments. (N.D.). Colonial period of Indonesia. Available: http://www.indonesiainvestments.com/culture/politics/colonial-history/item178. (Accessed 22 January 2015).

Kam, W.P. \& Kee, K.N. (2009). Batam, Bintan and Karimun: Past History and Current Development Towards Being A SEZ. Available: http://lkyspp.nus.edu.sg/aci/wpcontent/uploads/sites/4/2013/04/BBK_Past_History_and Current_Development_Towards_Being_A_SEZ_24Aug09.pdf. (Accessed 26 July 2014).

Laverty, A. (2007). Impact of Economic and Political Sanctions on Apartheid. Available: http://theafricanfile.com/politicshistory/impact-of-economic-and-political-sanctions-onapartheid/. (Accessed 22 January 2015).

Malaysia. Laws of Malaysia. (1990). Free Zones Act, No. 438 of 1990. 1-45. Available: http://www.agc.gov.my/Akta/Vol.\%209/Act\%20438.pdf. (Accessed 3 June 2014).

Malaysia. Free Zones Regulations of 1991. In: Laws of Malaysia. (2012). Laws and regulations applicable to the Malaysia Royal Customs Department. Kuala Lumpur: MDC Publishers.

Malaysia Investment Development Authority. (2012). About MIDA. Available http://www.mida.gov.my/home/about-mida/posts/. (Accessed 22 June 2014).

Malaysia Investment Development Authority. (2013). Investment in the manufacturing sector: Policies, incentives and facilities. Available:

http://www.mida.gov.my/env3/uploads/Publications_pdf/Malaysialnvestment_Policies_Icentives_F acilities/MIMS(E)_V1.pdf. (Accessed 10 June 2014).

National Treasury. (2008). Medium-term budget policy statement. Available: http://www.treasury.gov.za/documents/mtbps/2008/mtbps/MTBPS\%20full.pdf. (Accessed 8 May 2014). 
Organisation for Economic Development. (2010). OECD Investment Policy Reviews: Indonesia. Available: http://browse.oecdbookshop.org/oecd/pdfs/product/201004le.pdf. (Accessed 3 August 2014).

Ratuva, S. (2013). Politics of preferential development. Available: http://0press.anu.edu.au.innopac.up.ac.za/wp-content/uploads/2013/07/whole3.pdf. (Accessed 17 June 2015).

Robbins, T. (2014). Life change quotes. Available: http://lifechangequotes.com/tony-robbinsquote-change-is-inevitable-progress-is-optional/. (Accessed l December 2014).

Rogerson, C.M. (1974). Growth Point Problems-the Case of Babelegi, Bophutatswana. The Journal of Modern African Studies, 12, pp 126-130. Available: http://0-

journals.cambridge.org. innopac.up.ac.za/action/displayAbstract?fromPage $=$ online\&aid $=2504104 \& \mathrm{fi}$ leld=S0022278X00009022. (Accessed 26 May 2015).

Sala-i-Martín, X. \& Schwab, K. (2013). Global competitiveness report 2013-2014: Full data edition. Available: http://reports.weforum.org/the-global-competitiveness-report-2013-2014/.. (Accessed 2 February 2014).

Sivananthiran, A. (2009). Promoting Decent Work in Export Promotion Zones in Indonesia. Available: http://www.ilo.int/public/french/dialogue/download/epzindonesie. Pdf. (Accessed 2 August 2014).

South Africa. (2013). Employment Tax Incentive Act, No. 26 of 2013. Government Gazette, 582(37185): 1-21. Available: http://jutalaw.co.za/media/filestore/2014/03/Act_26_of_2013__Employment_Tax_Incentive_Act.pdf. (Accessed 3 May 2014).

South Africa. (1962). Income Tax Act, No. 58 of 1962. In: Lexis Nexis. 2013. Professional Tax Handbook 2013/2014. 23rd ed. Durban: Lexis Nexis.

South Africa. Minister of Trade and Industry. (2013). Special Economic Zones Bill. Available: http://www.thedti.gov.za/parliament/sez_bill2013.pdf. (Accessed 8 January 2014).

South Africa. (2014). Special Economic Zones Act, No. 16 of 2014. Government Gazette, 587(37664): 1-36. Available: http://www.google.co.za/url?South

Africa $=$ t\&rct $=j \& q=$ \&esrc $=s \&$ frm $=1$ \& source $=$ web\&cd $=1$ \&ved $=0$ CBs PFjAA\&url $=$ http $\% 3 A \% 2 F \% 2 F w w w . g o v . z$ a\%2Fdocuments\%2Fdownload.php\%3Ff\%3D213445\&ei=VXrfU5m6ltCh7Aa_54GABP\&usg=AFPjCNFX]IyL zfAxHLe6q3dG8AQggZRv-g\&bvm=bv.72197243,d.bGQ. (Accessed 3 May 2014).

The International Statistics Institute. (n.d.). Developing Countries. Available: http://www.isiweb.org/component/content/article/5-root/root/81-developing. (Accessed: 21 January 2015).

Thomas, T. (2011). The Malaysian insider. Remembering 500 years of colonialism. Available: http://www.themalaysianinsider.com/sideviews/article/remembering-500-years-of-colonialismtommy-thomas. (Accessed 22 January 2015).

Tiro, G. (2014). Son of Babelegi. MA Journalism and Media Studies Research Report. Available: http://wiredspace.wits.ac.za/bitstream/handle/10539/17054/FinalDraft.pdf?sequence=2. (Accessed 26 May 2015).

Trading Economics. (2014). South Africa unemployment rate. Available: http://www.tradingeconomics.com/south-africa/unemployment-rate. (Accessed 22 January 2015). United Nations Development Programme. (2006). Malaysia international trade, growth, poverty and human reduction development. Available:

http://www.undp.org.my/uploads/UNDP_Booklet_PDF_FORMAT.pdf. (Accessed 3 June 2014). 
Wahyuni, S., Anoviar, A.N \& Santoso, A.J. (2012). The Key success factors of Penang as the Silicon Valley of the East. SBS Journal of Applied Business, 1:1-18. Available:

http://jabr.sbs.edu/voll/wahyuni_et_al.pdf. (Accessed 3 June 2014).

World Bank. (2014). GDP Ranking. Available: http://data.worldbank.org/data-catalog/GDPranking-table. (Accessed: 22 January 2015).

World Bank. (2015a). GIN/ index (World Bank estimate). Available:

http://data.worldbank.org/indicator/SI.POV.GINI. (Accessed 22 January 2015).

World Bank. (2015b). Countries and Economies. Available: http://data.worldbank.org/country. (Accessed 22 January 2015). 